\title{
Correction to: Efficacy and safety of tetramethylpyrazine phosphate on pulmonary hypertension: study protocol for a randomized controlled study
}

Yuqin Chen ${ }^{1+}$, Wenjun He ${ }^{1+}$, Haiping Ouyang ${ }^{1}$, Chunli Liu' ${ }^{1}$, Cheng Hong ${ }^{1}$, Tao Wang ${ }^{1}$, Kai Yang ${ }^{1}$, Wenju Lu ${ }^{1}$ and Jian Wang ${ }^{1,2^{*}}$

Correction to: Trials (2019) 20:725

https://doi.org/10.1186/s13063-019-3770-0

After publication of our article [1] the authors have notified us of two typos in the Trial status.

- Originally published phrase

Recruitment started in September 2018 and is planned to end in October 2018, with 120 patients randomized. Treatment with TMP finished in October 2019. We disposal the data at present. The current protocol version is 2.0, dated 28 September 2018.

- Correct phrase

Recruitment started in September 2018 and is planned to end in October 2019, with 120 patients randomized. Treatment with TMP will be finished in March 2020. We disposal the data at present. The current protocol version is 2.0, dated 28 September 2018.
Published online: 30 March 2020

\section{Reference}

1. Chen $Y$, et al. Efficacy and safety of tetramethylpyrazine phosphate on pulmonary hypertension: study protocol for a randomized controlled study. Trials. 2019;20:725. https://doi.org/10.1186/s13063-019-3770-0.

The original article can be found online at https://doi.org/10.1186/s13063019-3770-0

* Correspondence: jianwang1@email.arizona.edu

${ }^{\dagger}$ Yuqin Chen and Wenjun He contributed equally to this work.

'State Key Laboratory of Respiratory Disease, National Clinical Research Center for Respiratory Disease, Guangzhou Institute of Respiratory Health, The First Affiliated Hospital of Guangzhou Medical University, 151 Yanjiang Road, Guangzhou, Guangdong 510120, People's Republic of China ${ }^{2}$ Division of Translational and Regenerative Medicine, Department of Medicine, The University of Arizona College of Medicine, Tucson, AZ, USA

(c) The Author(s). 2020 Open Access This article is licensed under a Creative Commons Attribution 4.0 International License which permits use, sharing, adaptation, distribution and reproduction in any medium or format, as long as you give appropriate credit to the original author(s) and the source, provide a link to the Creative Commons licence, and indicate if changes were made. The images or other third party material in this article are included in the article's Creative Commons licence, unless indicated otherwise in a credit line to the material. If material is not included in the article's Creative Commons licence and your intended use is not permitted by statutory regulation or exceeds the permitted use, you will need to obtain permission directly from the copyright holder. To view a copy of this licence, visit http://creativecommons.org/licenses/by/4.0/ The Creative Commons Public Domain Dedication waiver (http://creativecommons.org/publicdomain/zero/1.0/) applies to the data made available in this article, unless otherwise stated in a credit line to the data. 